\title{
INVENTORY INVESTMENT AND CASH FLOW SENSITIVITY: EVIDENCE FROM TURKISH FIRMS ${ }^{1}$
}

\author{
DOI: 10.17261/Pressacademia.2020.1223 \\ JBEF- V.9-ISS.2-2020(10)-p.182-188 \\ Omer Faruk Tan', Emin Avci² \\ ${ }^{1}$ Marmara University, Faculty of Business Administration, Department of Accounting and Finance, Istanbul, Turkey. \\ omer.tan@marmara.edu.tr, ORCID: 0000-0002-8875-4696 \\ ${ }^{2}$ Marmara University, Faculty of Business Administration, Department of Accounting and Finance, Istanbul, Turkey. \\ eavci@marmara.edu.tr, ORCID: 0000-0003-3172-897X
}

Date Received: April 25, 2020

Date Accepted: June 18, 2020

To cite this document

Tan, O.F., Avci, E., (2020). Inventory investment and cash flow sensitivity: evidence from Turkish firms. Journal of Business, Economics and Finance (JBEF), V.9(2), p.182-188.

Permanent link to this document: http://doi.org/10.17261/Pressacademia.2020.1223

Copyright: Published by PressAcademia and limited licensed re-use rights only.

\begin{abstract}
Purpose - This study analyzes the inventory investment - cash flow sensitivity for 166 manufacturing firms in Turkey listed in Borsa Istanbul. The time spans 2006-2018.

Methodology - Based on the previous literature, Lovell's (1961) target adjustment model is used. The baseline equation model is estimated by the system Generalized Method of Moments (GMM).

Findings- The relationship between inventory investment and cash flow is statistically positive for constrained firms, while insignificant for unconstrained firms according to all models. The effect of Gross Domestic Product (GDP) on inventory investment is positive and significant for both constrained and unconstrained firms, this implies that GDP contributes to an increase in inventory investment.

Conclusion- This study is the first one that analyzes the inventory investment and cash flow relationships for Turkish manufacturing firms and want to fulfill this gap in the literature. It is found that cash flow is positively significant for constrained firms according to size and age classification criteria.
\end{abstract}

Keywords: Inventory management, cash flows, Turkey, GMM Model, financial constraints.

JEL Codes: D80, G30, G31

\section{INTRODUCTION}

Firms generally prefer to use internally generated funds for investment activities like employment level, fixed investments, R\&D and inventories. Among these investments, inventories have some unique futures. Inventories are accepted as a vital reflection of economic conditions and business activities; such that, inventory investment is a significant factor to be examined when assessing a business cycle within an economy. For example, Blinder \& Maccini (1991) observed that inventory investment declined by $87 \%$ in the U.S. during a postwar downturn. As a result, macroeconomic fluctuations are reflected in the level of total inventories, because inventories have lower adjustment costs when compared other investment activities. For manufacturing firms, total inventories are embodied important part of total assets. A decline in inventory is useful in balancing the decrease in cash flows, especially during economic recession (Carpenter et al., 1994). On the other hand, inventory management strategy of a firm bay be affected by the financial constraints that the firm is facing. The paper by Fazzari et al. (1998) find that if external

\footnotetext{
${ }^{1}$ This study is a part of an ongoing doctoral thesis "Financial Decisions and Financial Constraints: Evidence from Emerging Markets" by PhD candidate Ömer Faruk Tan under the supervision of Professor Emin Avcl (PhD) of the Social Sciences Institute of Marmara University in the department of Finance and Accounting.
} 
financing is more costly than internal financing because of agency costs, moral hazard and asymmetric information problems; thus, investment will be more sensitive to cash flows for constrained firms. The relationship between inventory investment and cash flow in developed countries such as U.S. and U.K has been studied, but there has been little research on the same relationship in the context of emerging economics. Carpenter et al., (1994) is the first study to examine the relationship between inventory investment and cash flow sensitivity in U.S. firms. According to their analysis, although investment-cash flow sensitivity is significant for both large and small firms, the effect is heightened in small firms. They get also similar results when they classify firms whether firms have bond ratings or not. Kashyap et al., (1994) examine the inventory behavior of U.S.A. firms by using cash stock as a financial constraint proxy. They find that firms without access to bond markets are significantly constrained by limitations on liquidity. Gertler \& Gilchrist (1994) analyze manufacturing firms in the U.S. and observe that small firms are more sensitive than large firms to monetary tightening. They assert that coverage ratio can be used to identify financially constrained firms. Carpenter et al., (1998)' analysis employed three variables: cash stock, coverage ratio and cash flow as a financial constraints proxy. Cash flow is better to identify inventory investment for financially constrained firms.

Guariglia (1999) examine the inventory cash flow relationship for U.K. and place a special emphasis on total inventories, work-in process and raw materials. She finds that financial constraints affects work-in process and raw materials more than total inventories; this indicates adjustment costs related to total inventories are lower. (Guariglia, 2000) also use a structural linear quadratic model to analyze U.K. firms. In that study, she examines that financially constrained firms who have a low coverage ratio and higher short-term debt to inventories are more sensitive. (Guariglia \& Mateut, 2006) test the inventory investment-cash flow sensitivity with trade of channel of monetary transmission in U.K. over the period 1980-2000. Coverage ratio and trade credit to assets ratio are used for classification. They find that use of trade credit can balance the liquidity constraint of U.K. firms. Guariglia \& Mateut (2010) conduct an analysis of U.K. firms by classifying them as either exporter, a foreign-owned firm, or domestic firm. They conclude that domestic firms are more constrained than the others.

Small (2000) examines 527 U.K firms between 1977-2004. It is used current ratio, coverage ratio and size to categorize the firms. Unlike previous studies, the coverage and size criterion does not reduce the impact of cash flow on inventory investment for financially constrained firms. Cunningham (2004) research about 166 publicly traded Canadian firms for the 1992-1994 period with the quarterly data. The classification schemes of firms are size, age and bond rating. According to the results, he does not find any difference between both constrained and unconstrained firms in Canada. Tsoukalas (2006) utilize panel of 385 U.S.A manufacturing firms in the period 1975 and 1994 with the mean group estimator. It is found that, small firms exhibit higher inventory - cash flow sensitivity than larger firms.

Bo et al., (2002) investigate 82 Dutch firms from 1984 to 1995 using an augmented model of Lovell's target adjustment model (1961). Firms are categorized according to their dividend payout ratio, size and debt. They reveal that financially constrained firms in the Netherlands show significant inventory-cash flow sensitivity. Since large firms are multinationals, they do not exhibit inventory-cash flow sensitivity. Bagliano \& Sembenelli (2004) compare the U.K, French and Italian firms by age and size category. They find that although small and young firms are more sensitive in all countries, young and small firms in Italy are more sensitive than the others. Benito (2005) compare 3905 Spanish and 926 U.K. manufacturing and retail firms for the period 1985-2000. They conclude that cash flow and liquidity effects exist in both countries, but they are much stronger for U.K. firms. Since the U.K. financial system is market-based, while that of the Spain is bank-based, this is interpreted as contrary to the bank dependency hypothesis. Cunha (2010) analyze the Portuguese firms between 1990 and 2000. Firms are categorized according to their interest coverage ratio. Firms with lower coverage ratio demonstrate higher inventory-cash flow sensitivity. Sangalli (2013) investigate the Italian firms between 1991-2009 according to the coverage ratio, acid test ratio and multivariate proxy for risk (CEBI- Centrale dei Bilanci ratings). It is found that financially constrained firms indicate higher inventory - cash flow sensitivity than financially unconstrained firms.

Yue (2011) categorize Chinese firms according to its size, region and ownership structure. Firms, which are private or located in coastal region display significant inventory investment-cash flow relationships. Yang et al., (2016) demonstrate that with an increase in financial development, a firm's inventory investment increase as well.

In this study, the link between inventory investment and cash flow is investigated for both constrained and unconstrained firms. To round the literature, to the best of our knowledge, this study is the first one to examine the link between inventory investment and cash flow in both constrained and unconstrained firms in Turkey. The remainder of this study is organized as follows. Section 2 gives information about the data and methodology. Section 3 covers the empirical findings and discussions. Finally, section 4 is the conclusion part. 


\section{DATA AND METHODOLOGY}

In this study, Turkish manufacturing firms listed in Borsa Istanbul (BIST) are analyzed. The study spans 2006-2018. We acquire the data from Thomson Reuters Datastream and Thomson Reuters Eikon. Age information of the firms are taken manually. Missing values are taken from the annual financial reports of each firm. Manufacturing firms with at least four years of consecutive data are selected. Applying the selection criteria resulted in unbalanced panel data containing 166 manufacturing firms. All variables are winsorized at $1^{\text {st }}$ and $99^{\text {th }}$ percentiles to minimize the effect of outliers. Table 1 shows the definition of each variables.

Table 1: Definition of Variables

\begin{tabular}{ll}
\hline Explanatory Variables & Definitions \\
\hline INVENTORY & Natural logarithm of total inventories. \\
SALES & Natural logarithm of annual total sales. \\
CASH FLOW & $\begin{array}{l}\text { Net income before extraordinary items and } \\
\text { depreciation/amortization to total assets. }\end{array}$ \\
GDP & Annual growth rate (\%) \\
\hline
\end{tabular}

Age and size are selected as financial constraint criteria in the study. Determining the existence of financial constraints, size and age are accepted as the most useful methods (Beck, Demirgüç-Kunt, Laeven, \& Maksimovic, 2006). Following previous studies (Carpenter et al., 1994; Gertler \& Gilchrist, 1994; Gilchrist \& Himmelberg, 1995; Guariglia \& Mateut, 2010; Schiantarelli \& Sembenelli, 2000; Yue, 2011), firms are ranked in each country on the basis of their total assets and classify them as financially constrained (unconstrained) if their size is below (above) the median size value. Because of moral hazard, agency costs and asymmetric information problems, smaller firms require more internal funds.

According to the age criteria, younger firms are not well known, and public information is less about these firms (Guariglia \& Mateut, 2010). Firms are assigned in each country and categorize them as financially constrained (unconstrained) if their age is below (above) the median age value (Arslan, Florackis, \& Ozkan, 2006; Guariglia \& Mateut, 2010; Schiantarelli \& Sembenelli, 2000)

Based on the previous literature, Lovell's (1961) target adjustment model is used (Guariglia \& Mateut, 2010; Sangalli, 2013; Shiau, Chang, \& Yang, 2018; Yue, 2011). Inv and Sales denote the natural logarithm of total inventories and total sales respectively.

$\Delta l n v_{i, t}=\beta_{o}+\beta_{1} \Delta l n v_{i, t-1}+\beta_{2} \Delta$ Sales $_{i, t}+\beta_{3} \Delta$ Sales $_{i, t-1+} \beta_{4}\left(\operatorname{lnv}_{i, t-1}\right.$ Sales $\left._{i, t-1}\right)+\beta_{5} C_{i, t-1}+\lambda_{i}+\eta_{t}+\mu_{j}+\exists_{i t}(1)$

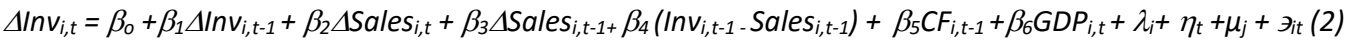

Where, $\Delta l n v$ is the difference of the natural logarithm of total inventories at time $t$ and $t-1, \Delta$ Sales is the difference of the natural logarithm of sales at time $t$ and $t-1$ respectively. Differences of natural logarithms and sales capture the short-term dynamics. $\left(\right.$ Inv $_{i, t-1}$-Sales St $\left.-1_{1}\right)$ influences the long-term target level, which gives information about the error-correction format. When inventory is lower than the target level (Sales), the future inventory investment would be higher or vice a versa. The error correction term should be negative. CF is cash flow scaled by total assets at time $t-1$. GDP is an annual growth rate at time $t, \lambda_{1}$ is a firm-fixed effects, $\eta_{t}$ is time effects, $\mu_{j}$ is industry effects and $\xi_{i t}$ is an error term. Model 1 is our baseline model, which includes cash flow. Model 2 also contains GDP growth rate.

The baseline equation model is estimated by the system GMM model created by (Arellano \& Bover, 1995; Blundell \& Bond, 1998) with orthogonal transformation is applied to overcome potential endogeneity and heterogeneity issues and eliminate the problem of autocorrelation. A two-step system GMM model is applied and included Windmeijer's (2005) correction for standard errors. As suggested by (Roodman, 2009), instruments are collapsed to prevent too many variables. The system GMM use both a level equation model and a first-order difference equation model. The second and more lagged instruments are used, and all explanatory variables are treated as endogenous or predetermined variables. GDP variable is treated as exogenous variable. 


\section{FINDINGS AND DISCUSSIONS}

Table 2 provides information on descriptive statistics. The mean of the natural logarithm of total inventories and total sales are 9.88 and 11.67 , respectively. Cash flow to total ratio is approximately \%7. The mean of GDP is \%5.1 during the study period. The variance inflation factor (VIF) gives information about whether there is multicollinearity between variables. IF the VIF is greater than 5 or 10, the multicollinearity is high in the regression model (Guizani, 2017). The mean VIF is 1.10 , so there is no multicollinearity problem among our variables.

Table 2: Descriptive Statistics

\begin{tabular}{lcccccc}
\hline Variables & Mean & Median & Std. Dev. & Q25 & Q75 & VIF \\
\hline Inventories & 9.8853 & 9.9555 & 1.6846 & 8.798 & 10.8751 & \\
Sales & 11.6694 & 11.587 & 1.7496 & 6.4514 & 12.7246 & 1.02 \\
CF/TA & 0.0694 & 0.0659 & 0.1923 & 0.0178 & 0.1195 & 1.02 \\
GDP (\%) & 5.12 & 5.3 & 3.71 & 3.3 & 7.3 & 1 \\
\hline $\begin{array}{l}\text { Note: Inventories is the natural logarithm of total inventories. Sales is the natural logarithm of annual } \\
\text { total sales. CF/TA is the ratio cash flow to total assets. GPD is the annual growth rate. VIF is the variance } \\
\text { inflation factor. }\end{array}$
\end{tabular}

Table 3 displays the results of investment - cash flow sensitivity according to the size criteria. According to the analysis, the coefficient of lagged inventory investment is negative and significant for both constrained and unconstrained firms. This implies that firms adjust their target levels from the actual to the desired inventory stock (Carpenter et al., 1994; Guariglia \& Mateut, 2010; Sangalli, 2013). Current sales have positive and significant effects that are stronger for unconstrained firms. Lagged sales are insignificant for both types of firms. The error correction term is negative and statistically significant because of inventory is lower than the target level (Sales), the future inventory investment would be higher or vice a versa. The coefficient of cash flow is our main interest, and it is statistically positive and significant for constrained firms, while insignificant for unconstrained firms according to all models. The result of the study are consistent with the previous literature (Carpenter et al., 1994, 1998; Gilchrist \& Himmelberg, 1995; Boo et al., (2002). The coefficient of small firms (0.1008) are two times higher than large firms (0.0449). This result confirms the hypothesis and show that small firms need more internal funds because of asymmetric information, agency cost problems GDP is positive and significant for both constrained and unconstrained firms, this implies that GDP contributes to an increase in inventory investment.

Table 3: Estimation Results According to Size Criteria

\begin{tabular}{|c|c|c|c|c|}
\hline \multirow{2}{*}{\multicolumn{3}{|c|}{ Dependent Variable: $\Delta \operatorname{In} v_{l, t}$}} & \multirow{2}{*}{\multicolumn{2}{|c|}{ NFC }} \\
\hline & & & & \\
\hline & 1 & 2 & 1 & 2 \\
\hline \multirow[t]{2}{*}{$\Delta \operatorname{In} v_{i, t-1}$} & $-0.08967 *$ & $-0.09599 *$ & $-0.15007^{* * *}$ & $-0.15489 * * *$ \\
\hline & $(0.054)$ & $(0.053)$ & $(0.052)$ & $(0.051)$ \\
\hline \multirow[t]{2}{*}{$\Delta$ Salesi,$t$} & $0.20044 * *$ & $0.19621 * *$ & $0.52688 * * *$ & $0.54303^{* * *}$ \\
\hline & (0.096) & (0.091) & $(0.087)$ & $(0.086)$ \\
\hline \multirow[t]{2}{*}{$\Delta$ Sales $_{i, t-1}$} & 0.11308 & 0.10747 & 0.06905 & 0.06535 \\
\hline & $(0.078)$ & $(0.078)$ & $(0.065)$ & $(0.063)$ \\
\hline \multirow[t]{2}{*}{ Invit,-1 - Sales $i_{i, t-1}$} & $-0.18560 * *$ & $-0.18367^{* *}$ & $-0.31123 * * *$ & $-0.30716^{* * *}$ \\
\hline & $(0.086)$ & $(0.085)$ & $(0.079)$ & $(0.077)$ \\
\hline \multirow[t]{2}{*}{$C F_{i, t-1}$} & $0.10086^{* * *}$ & $0.10308 * * *$ & 0.04496 & 0.04514 \\
\hline & $(0.034)$ & $(0.033)$ & $(0.258)$ & $(0.259)$ \\
\hline
\end{tabular}




\begin{tabular}{|c|c|c|c|c|}
\hline$G D P_{i, t}$ & & $\begin{array}{c}0.02446 * * * \\
(0.004)\end{array}$ & & $\begin{array}{c}0.02048^{* * *} \\
(0.003)\end{array}$ \\
\hline YEAR & YES & YES & YES & YES \\
\hline INDUSTRY & YES & YES & YES & YRS \\
\hline Observations & 809 & 809 & 876 & 876 \\
\hline ar1 & $-4.60 * * *$ & $-4.55^{* * *}$ & $-4.31 * * *$ & $-4.29 * * *$ \\
\hline ar2 & -0.94 & 0.328 & $-2.11^{* *}$ & $-2.11^{* *}$ \\
\hline ar3 & - & - & 1.58 & 1.55 \\
\hline Hansen & $25.56(22)$ & $26.18(22)$ & $25,28(14)$ & $25,96(14)$ \\
\hline
\end{tabular}

Table 4 exhibits the results of investment - cash flow sensitivity according to the age criteria. As in Table 3, the coefficient of lagged inventory investment is negative and significant for both constrained and unconstrained firms. The coefficient of financially constrained firms two times higher than financially constrained firms. This implies that unconstrained firm adjust their target faster than constrained firms. Current sales are significant for both type of firms, but stronger for unconstrained firms. As in Table 3 , the error correction term is negative for both of them, but significant only for constrained firms. The coefficient of cash flow is statistically positive and significant for constrained firms, while insignificant for unconstrained firms according to all models. The coefficient of small firms (0.0948) are approximately two times higher than large firms (0.0587). According to the hypothesis, younger firms are not well known, and public information is not enough for them, while old firms have a reputation in the market. The result is consistent with the hypothesis and previous studies as size criteria.

Table 4: Estimation Results According to Age Criteria

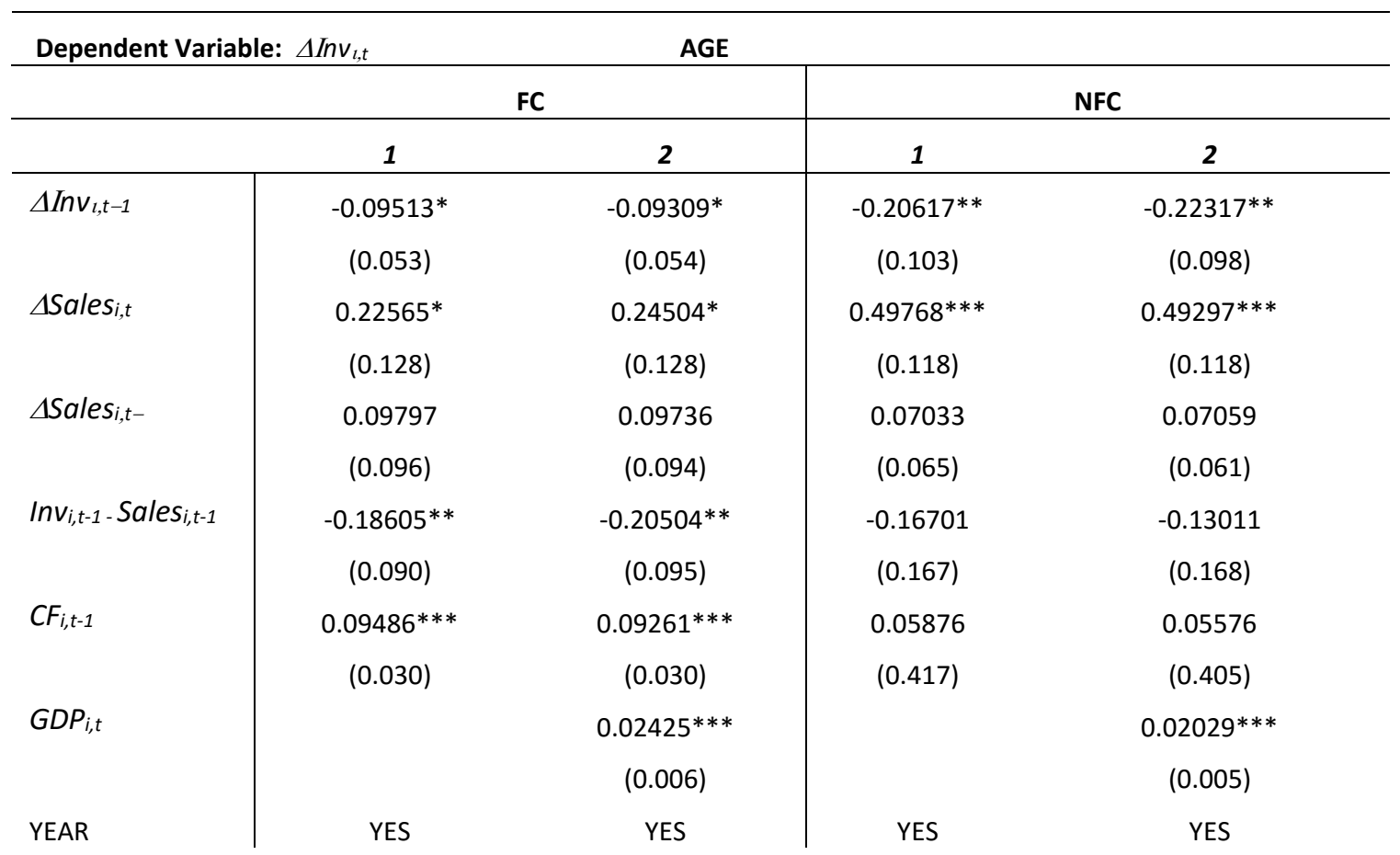




\begin{tabular}{|c|c|c|c|c|}
\hline INDUSTRY & YES & YES & YES & YES \\
\hline Observations & 804 & 804 & 884 & 884 \\
\hline ar1 & $-4.7^{* * *}$ & $-4.59 * * *$ & $-4.00 * * *$ & $-3.97 * * *$ \\
\hline ar2 & -1.22 & -1.22 & -1.17 & -1.25 \\
\hline Hansen & $31.50(22)$ & $32.97(22)$ & $43.96(26)$ & $44.41(26)$ \\
\hline
\end{tabular}

\section{CONCLUSION}

In this study, we analyze the inventory investment - cash flow sensitivity for 167 listed firms in Borsa Istanbul. 2006-2018 is chosen as the study period. Lovell's (1967) target adjustment model is applied and the system GMM model is used for the analysis. While classifying firms as financially constrained and unconstrained, it is considered the size and age criterion most frequently used in the literature. To the best of our knowledge, this study is the first one that analyzes the inventory investment and cash flow relationships for Turkish manufacturing firms. First of all, firms prefer to use their internal funds for their investment behaviors. The main investment activities for firms are fixed investments, research and development, training of employment and inventories. Among these, inventory has an important place in total assets. Since the adjustment costs of inventories are cheaper than others, firms can reduce or increase their inventory more quickly in any fluctuations in the economy. According to analysis in the study, we find that cash flow is positively significant for constrained firms, but not significant for others, according to size and age classification criteria. The results confirm the hypothesis that external financing is costly for small and young firms so, sensitivity of internal funds is higher for those firms. The coefficient of small and young firms are approximately two times higher than old and big firms. The effect of GDP on inventory investment is positive and significant for both constrained and unconstrained firms, this denotes that GDP contributes to an increase in inventory investment. For further study, academicians/researchers analyze investment cash flow sensitivity for the specific terms such as global financial crisis in 20082009, the Turkish economic crisis in 2001, the quantitative easing era of 2010-2014, and so on. Also, there are many other emerging markets available for analysis.

\section{REFERENCES}

Arellano, M., \& Bover, O. (1995). Another look at the instrumental variable estimation of error-components models. Journal of Econometrics, 68(1), 29-51. https://doi.org/10.1016/0304-4076(94)01642-D

Arslan, Ö., Florackis, C., \& Ozkan, A. (2006). The role of cash holdings in reducing investment-cash flow sensitivity: Evidence from a financial crisis period in an emerging market. Emerging Markets Review, 7(4), 320-338. https://doi.org/10.1016/j.ememar.2006.09.003

Bagliano, F. C., \& Sembenelli, A. (2004). The cyclical behaviour of inventories: European cross-country evidence from the early 1990s recession. Applied Economics, 36(18), 2031-2044. https://doi.org/10.1080/0003684042000295601

Beck, T., Demirgüç-Kunt, A., Laeven, L., \& Maksimovic, V. (2006). The determinants of financing obstacles. Journal of International Money and Finance, 25(6), 932-952. https://doi.org/10.1016/j.jimonfin.2006.07.005

Benito, A. (2005). Financial pressure, monetary policy effects and Inventories : Firm-level evidence from a market-based and a bank-based financial system. Economica, 72, 201-224.

Blundell, R., \& Bond, S. (1998). Initial conditions and moment restrictions in dynamic panel data models. Journal of Econometrics, 87(1), 115143. https://doi.org/10.1016/S0304-4076(98)00009-8

Bo, H., Kuper, G., Lensink, R., \& Sterken, E. (2002). Dutch inventory investment: Are capital market imperfections relevant? Applied Economics, $34,15-22$.

Carpenter, R. E., Fazzari, S. M., \& Petersen, B. C. (1998). Financing constraints and inventory investment: A comparative study with highfrequency panel data. Review of Economics and Statistics, 80(4), 513-519. 
Carpenter, R. E., Fazzari, S. M., Petersen, B. C., Kashyap, A. K., \& Friedman, B. M. (1994). Inventory investment, internal finance fluctuations, and the business cycle. Brokings Papers on Economic Activity, 1994(2), 75-138.

Cunha, J. (2010). The financing constraint hypothesis and inventory investment decisions of firms, 1-20.

Cunningham, R. (2004). Finance constraints and inventory investment : Empirical tests with panel data (38 No. 2004). Ottawa.

Gertler, M., \& Gilchrist, S. (1994). Monetary policy, business cycles, and the behavior of small manufacturing firms. Quarterly Journal of Economics, 109(2), 309-340.

Gilchrist, S., \& Himmelberg, C. P. (1995). Evidence on the role of cash flow for investment. Journal of Monetary Economics, $36,541-572$. https://doi.org/10.1016/0304-3932(95)01223-0

Guariglia, A. (1999). The effects of financial constraints on inventory investment: Evidence from a panel of UK firms. Economica, 66(261), 43-62.

Guariglia, A. (2000). Inventory investment and capital market imperfections: A generalization of the linear quadratic inventory model. Oxford Bulletin of Economics and Statistics, 62(2), 223-243.

Guariglia, A., \& Mateut, S. (2006). Credit channel, trade credit channel , and inventory investment : Evidence from a panel of UK firms. Journal of Banking \& Finance, 30, 2835-2856. https://doi.org/10.1016/j.jbankfin.2005.11.002

Guariglia, A., \& Mateut, S. (2010). Inventory investment, global engagement, and financial constraints in the UK: Evidence from micro data. Journal of Macroeconomics, 32, 239-250. https://doi.org/10.1016/j.jmacro.2009.03.001

Guizani, M. (2017). The financial determinants of corporate cash holdings in an oil rich country: Evidence from Kingdom of Saudi Arabia. Borsa Istanbul Review, 17(3), 133-143. https://doi.org/10.1016/j.bir.2017.05.003

Kashyap, A., Lamont, O. a, \& Stein, J. C. (1994). Credit conditions and the cyclical behavior of inventories. The Quarterly Journal of Economics, 109(3), 565-592. https://doi.org/10.2307/2118414

Lovell, M. (1961). Manufacturers' inventories, sales expectations, and the acceleration principle. Econometrica, 29(3), 293-314.

Roodman, D. (2009). Practitioners' corner: A note on the theme of too many instruments. Oxford Bulletin of Economics and Statistics, 71(1), 135-158. https://doi.org/10.1111/j.1468-0084.2008.00542.x

Sangalli, I. (2013). Inventory investment and financial constraints in the Italian manufacturing industry: A panel data GMM approach. Research in Economics, 67(2), 157-178. https://doi.org/10.1016/j.rie.2013.02.003

Schiantarelli, F., \& Sembenelli, A. (2000). Form of ownership and financial constraints: Panel data evidence from flow of funds and investment equations. Empirica, 27, 175-192. https://doi.org/10.1023/A:1026588619191

Shiau, H. L., Chang, Y. H., \& Yang, Y. J. (2018). The cash holdings and corporate investment surrounding financial crisis: The cases of China and Taiwan. Chinese Economy, 51(2), 175-207. https://doi.org/10.1080/10971475.2018.1447833

Small, I. (2000). Inventory investment and cash flow (No. 112). London - Bank of England.

Tsoukalas, J. D. (2006). Financing constraints and firm inventory investment: A reexamination. Economics Letters, 90(2), $266-271$. https://doi.org/10.1016/j.econlet.2005.08.012

Windmeijer, F. (2005). A finite sample correction for the variance of linear efficient two-step GMM estimators. Journal of Econometrics, 126(1), 25-51. https://doi.org/10.1016/j.jeconom.2004.02.005

Yang, J., Guariglia, A., Shi, Y., \& Peng, Y. (2016). Inventory investment and the choice of financing in China: Does city-level financial development play a role?

Yue, F. (2011). Financial constraints and firms' activities in China. Durham University. 